\title{
Antarctic fur seal (Arctocephalus gazella) annual migration and temporal patterns of on-shore occurrence of leucistic individuals on King George Island
}

\author{
Anna Grebieniow ${ }^{1} \cdot$ Małgorzata Korczak-Abshire $^{2}(1) \cdot$ Anna Gasek $^{3} \cdot$ Aleksandra Górecka-Bruzda $^{4}(\mathbb{0})$
}

Received: 15 October 2019 / Revised: 5 June 2020 / Accepted: 9 June 2020 / Published online: 17 June 2020

(c) The Author(s) 2020

\begin{abstract}
Non-invasive tracking the on-shore occurrence of the atypically pigmented animals and determination of land residency duration of leucistic seals would help us find out more about the rotation of the migrating population. During seven austral summer seasons (2011-2018), by counting the animals every 10 days at the Cape Lions Rump shore, King George Island, South Shetlands, in the Antarctic Specially Protected Area No. 151 and the adjacent ice-free land $\left(31.52 \mathrm{~km}^{2}\right)$ we registered fourteen leucistic individuals per a total of 43,919 animals. Moreover, daily monitoring of local fauna resulted in further 33 leucistic animals (together 47, in all seasons). Whilst the results of 10-day censuses of the total population were similar inter-seasonally, a tendency for increased occurrence of leucistic individuals in successive seasons was revealed. Generally, the number of animals increased significantly as season progressed. Since leucistic individuals stayed on-shore for 1-2 days usually, it can be hypothesised that the observation of migrating Antarctic fur seals every 3 days does not involve the same individuals. Also, additional every 5-day censuses taken in one season in ASPA 151 resulted in a higher seasonal number of animals, which proves that more frequent counts help us estimate population abundance more efficiently. Thus, every 5-day counts are proposed as a feasible and justified method of population monitoring.
\end{abstract}

Keywords Pinnipeds · Otariidae · Population rotation · ASPA $151 \cdot$ Lions Rump CEMP Site

\section{Introduction}

At the turn of the Nineteenth and Twentieth Centuries, due to intensive commercial sealing the population of Antarctic fur seal Arctocephalus gazella (Peters 1875) in South Georgia and South Shetlands was brought to the brink of extinction (Weddell 1825; Bonner 1968). The current number of Antarctic fur seal population was estimated at 4.5-6.2

Małgorzata Korczak-Abshire

mka@ibb.waw.pl

1 Polish Society for Nature Conservation "Salamandra", Stolarska 7/3, 60-788 Poznan, Poland

2 Institute of Biochemistry and Biophysics, Polish Academy of Sciences, Pawińskiego 5a, 02-106 Warsaw, Poland

3 Polish Academy of Sciences Botanical Garden - Center for Biological Diversity Conservation in Powsin, Prawdziwka 2, 02-973 Warsaw, Poland

4 Department of Animal Behaviour, Institute of Genetics and Animal Breeding Polish Academy of Science, Jastrzębiec, 05-552 Magdalenka, Poland million individuals (Hofmeyr 2016), with 97\% of individuals observed in South Georgia (Hoffman et al. 2018). In the South Shetlands, only Livingston Island and Elephant Island are locations of established breeding colonies of Antarctic fur seals (Bengtson et al. 1990; Reid et al. 2006), whilst on King George Island non-breeding males haul out during the moulting season (Sierakowski 1991; Salwicka and RakusaSuszczewski 2002; Korczak-Abshire et al. 2019). Although, Jabłoński et al. (1987) and Bengtson et al. (1990) reported a breeding site at Stigant Point, King George Island in seasons 1980/1981 and 1986/1987.

Nonetheless, the behaviour of Antarctic fur seals in the natural environment is not fully explored. When studying individual behaviour, it is important to know whether the subjects observed are the same or different animals. However, especially in the migratory periods, the individual non-invasive identification of morphologically similar animals living in colonies creates accuracy problems for the observers (Udevitz et al. 2005). Then, on successive days, observation may involve the same or different newly coming animals. Determination of the duration of land residency of 
not typically pigmented animals would help us approximate the rotation of migrating Antarctic fur seals. This would be also important when deciding about the statistics used (single $v s$. repeatable measures) in all kinds of species-related studies. Since leucistic individuals with light skin and dark eyes ("honey-blond", creamy white or yellow, Fig. 1) have been noted in this species (e.g. Acevedo et al. 2009; Romero and Tirira 2017), their on-shore occurrence and duration of land residency could be used as a preliminary indicator of the migratory population rotation. Moreover, given scarce documentation of population dynamics in recent years, approximation of the number of animals in this region seems justified. Also, the preliminary assessment of the feasibility of more frequent counts could be helpful in more accurate population dynamics.

Thus, the aim of this study was threefold, i.e. to (1) estimate the Antarctic fur seals occurrence at Cape Lions Rump shore, King George Island, the South Shetlands in seven austral summer seasons (2011-2018) with special reference to leucistic animals, (2) determine land residency of leucistic seals as reference individuals in the preliminary assessment of population rotation and to (3) test whether more frequent counts of population are feasible and justified. We believe that our data will broaden the present knowledge about leucistic Antarctic fur seals' temporal stay on King George Island.

\section{Materials and methods}

Since only a visual inspection was carried out, no experimentation was performed in accordance with European directive 2010/63/EU and Polish laws related to ethics of animal experimentation.

Data were collected between 5 November 2011 and 22 February 2018. The study area (Fig. 2a, b) was Cape Lions Rump (LR), a shore located at the mouth of King George Bay $\left(62^{\circ} 7^{\prime} 60^{\prime \prime} \mathrm{S}, 58^{\circ} 7^{\prime} 30^{\prime \prime} \mathrm{W}\right)$, within the Antarctic Specially Protected Area No. 151 (ASPA 151, $31.3 \mathrm{~km}^{2}$ ) and the adjacent ice-free area $\left(0.22 \mathrm{~km}^{2}\right)$, King George Island, South Shetland Islands. ASPA 151 is covered by the CCAMLR Ecosystem Monitoring Program of the Commission for the Conservation of Antarctic Marine Living Resources (Korczak-Abshire et al. 2013; Hinke et al. 2018; Gryz et al. 2018). Observations were carried along three different time scales. Each Antarctic summer season, between November and mid-March, all fauna species were monitored daily with routine monitoring (RDM) over fixed paths (Fig. 2b). However, only leucistic seals were counted. The total census of Antarctic fur seals was taken every 10 days along the same paths (10-day transects, 10DT), according to Sierakowski (1991). During the 2016/2017 season, in order to check whether more frequent counts were feasible and justified, every 5-day transects (5DT) were taken in ASPA 151 only.

Morphological characteristics of leucistic individuals, including i.e. an approximate size of an individual by nosetail length, length of whiskers, darker/lighter colouring of the fur (spots, patches), scars, possible wounds were recorded
Fig. 1 Leucistic individuals of Antarctic fur seal (Arctocephalus gazella) are easy to find in the crowd of fur seals from a distance. A group of animals at Cape Lions Rump, King George Island, South Shetlands, the Antarctic. Photo: A. Grebieniow

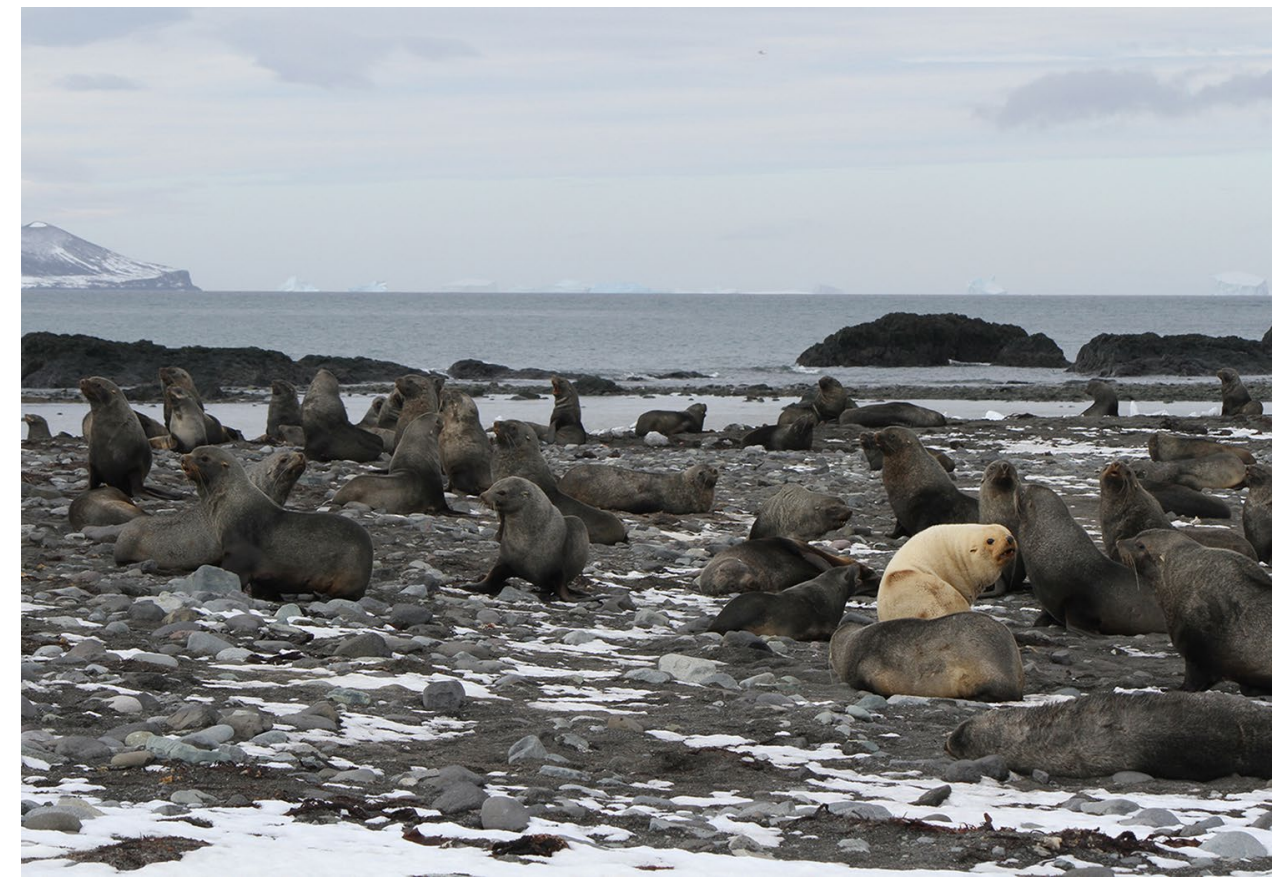


Fig. 2 Study area covered: a western shore of King George Bay on King George Island and b ASPA 151 and adjacent icefree area. Every 10-day (10DT), 5-day (5DT) and daily routine monitoring (RDM) paths are shown

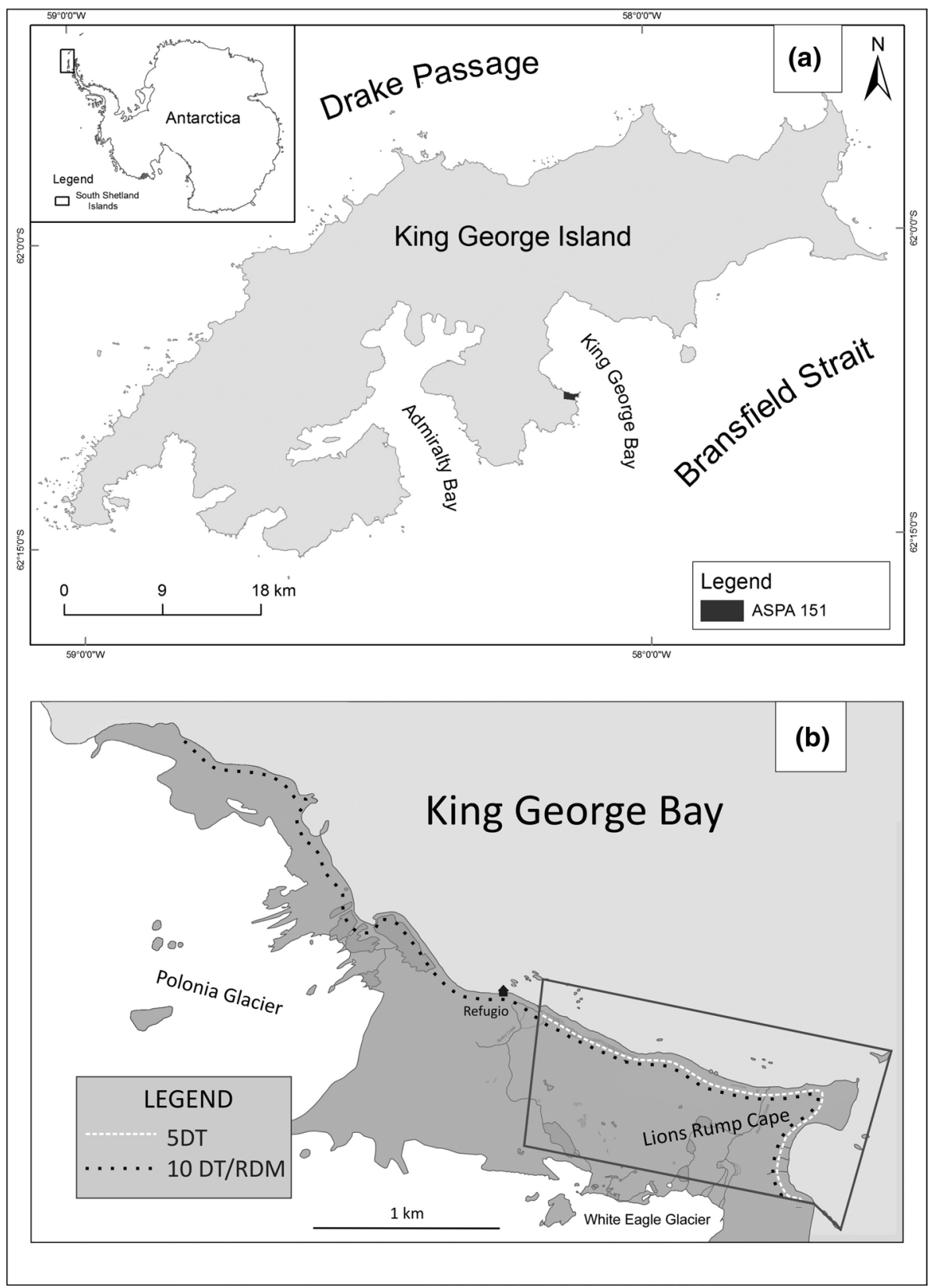

to facilitate identification on subsequent survey efforts and determine land residency periods. For documentation, the animals were approached quietly, at a distance which did not provoke their displacement. We assumed than an animal remained in one location throughout the period (days) it was observed ashore, regardless its possible short visits in the water. The mean number of animals and standard deviations for seasons and transects within the season were assessed. To assess the intra- and inter-seasonal trends in migratory residence (numbers of animals), linear regression per season and successive transect (10DT) were performed. A $\chi^{2}$ test was applied to compare the numbers of animals counted with 5DT and 10DT methods in the 2016/2017 season. The level of significance was set at $\alpha=0.05$. SAS 9.4 Statistical Package (SAS Institute Inc., Cary, NC, USA) was used for statistical analyses. Due to the small number of leucistic individuals, raw numbers of animals were presented. For land residency of leucistic seals, simple descriptive statistics (the median duration in days and its range) was shown.

\section{Results}

The population of Antarctic fur seals involved mainly adult males, whilst females or under-yearlings were noticed sporadically. The animals hauled out on the LR shore usually 
between December and March, and moulting was observed. The maximum numbers (summer peaks) of Antarctic fur seals recorded with 10DT in haul-outs were noted from February till mid-March (Table 1).

\section{Total abundance and the frequency of transects}

The total number of Antarctic fur seals assessed by 10DT was 43,919 , with $6274.2 \pm 3179.49$ individuals per season and $430.6 \pm 720.02$ per transect. Assessed with the linear regression, the total number of seals was similar in every season $\left(y=-1,694,818+844.2 \times X_{\text {season }}, r^{2}=0.3290\right.$; $p=0.1782,25 \% \mathrm{CL}=-541,75 \% \mathrm{CL}=2230.2$ ), Fig. 3a. Within seasons, $14.6 \pm 0.53$ transects per season were made. The number of recorded seals increased with each successive transect $\left(y=486.3+117.6 \times X_{\text {transect }} p<0.0001, r^{2}=0.4733\right.$; $25 \% \mathrm{CL}=93.1,75 \% \mathrm{CL}=142.5)$, Fig. $3 \mathrm{~b}$.

In the 2016/2017 season, the 5DT provided more extensive results as per total abundance compared to the 10DT.

Table 1 Dates with maximum numbers $\left(N_{\max }\right)$ of Antarctic fur seal individuals (summer peaks) assessed by 10DT on the LR shore (total ASPA 151 and adjacent ice-free area)

\begin{tabular}{llr}
\hline Season & Date of the summer peak & $N_{\max }$ \\
\hline $2011 / 2012$ & $10 / 03 / 2012$ & 1700 \\
$2012 / 2013$ & $20 / 02 / 2013$ & 409 \\
$2013 / 2014$ & $18 / 02 / 2014$ & 1475 \\
$2014 / 2015$ & $8 / 03 / 2015$ & 1327 \\
$2015 / 2016$ & $27 / 02 / 2016$ & 3487 \\
$2016 / 2017$ & $17 / 02 / 2017$ & 1762 \\
$2017 / 2018$ & $09 / 02 / 2018$ & 2356 \\
\hline
\end{tabular}

For the whole population, the counts were significantly higher by 6811 animals with the 5DT (12,167 individuals) compared to the 10DT (5356 individuals, $\chi^{2}$ test, $\chi^{2}{ }_{1}=2645$, $p<0.0001)$. Also, the date of the seasonal peak could be detected more accurately. The date of the highest abundance recorded with 5DT was 22 February 2017 (1897 individuals), whilst in the case of 10DT it was 17 February 2017 (1504 individuals, Fig. 4). Therefore, for the peaks an additional 393 animals were counted with the 5DT as compared to the 10DT (1897 and 1504 individuals, respectively), $\chi^{2}$ test, $\chi_{1}^{2}=28, p<0.0001$, Fig. 4 .

\section{Leucistic individuals}

The total number of leucistic Antarctic fur seals was 14 and 47 as assessed with 10DT and RDM methods, respectively (Table 2). Contrary to the total population census which remained stable in the period under investigation, the number of leucistic individuals tended to increase in successive seasons (linear regression, $y=-4958.82+2.46 \times X_{\text {season }}$, $r^{2}=0.5531, p=0.0553 ; 25 \% \mathrm{CL}=-0.082,75 \% \mathrm{CL}=5.01$ ). The median duration of land stay of leucistic seals on land was 1 day $($ median $=1,25$ th percentile $=1 ; 75$ th percentile $=3, \min =1 ; \max =6)$ as assessed by RDM.

\section{Discussion}

This study is the first one to summarize the fluctuation of male Antarctic fur seals population at cape Lions Rump (King George Island, South Shetlands) during the moulting period and the first one concerning leucistic individuals in this location. Our study showed that from 2011 to 2018
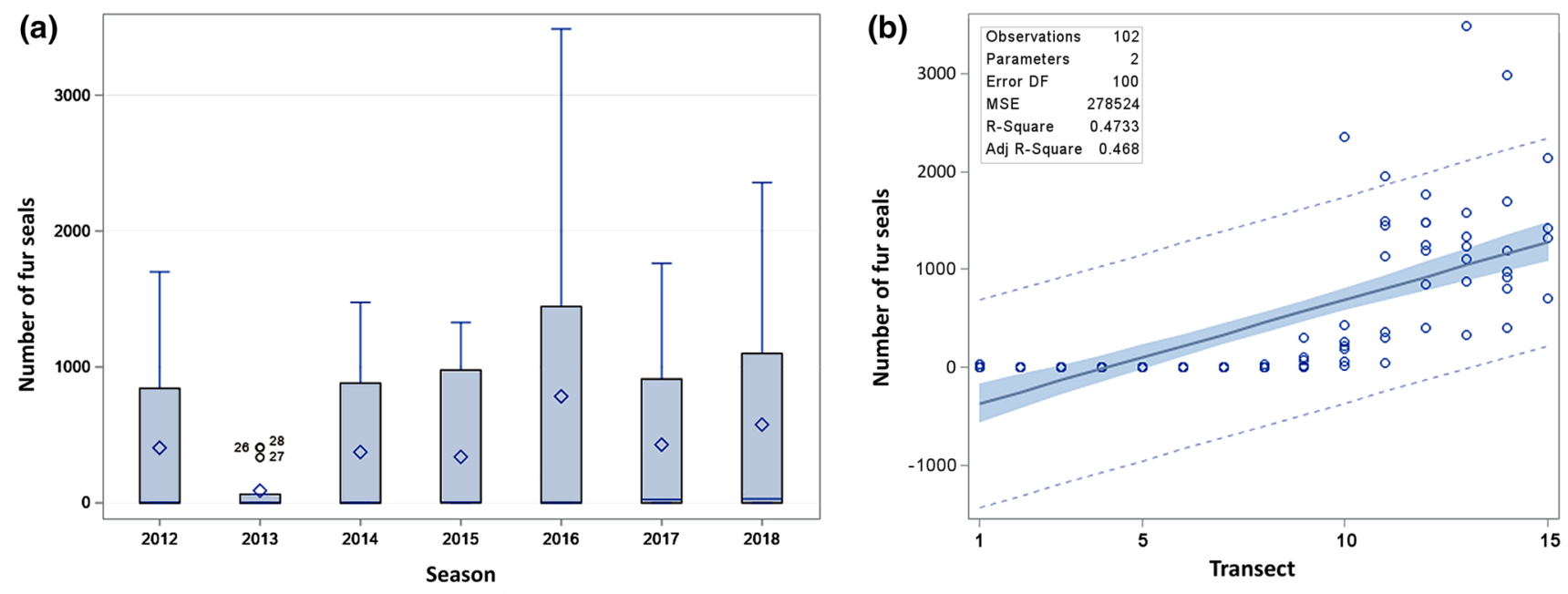

Fit $\square$ 95\% Confidence Limits

95\% Prediction Limits

Fig. 3 Data assessed by 10DT method: a the total abundance of Antarctic fur seals in investigated seasons and $\mathbf{b}$ fit plot for the number of seals in the consecutive transect registered 


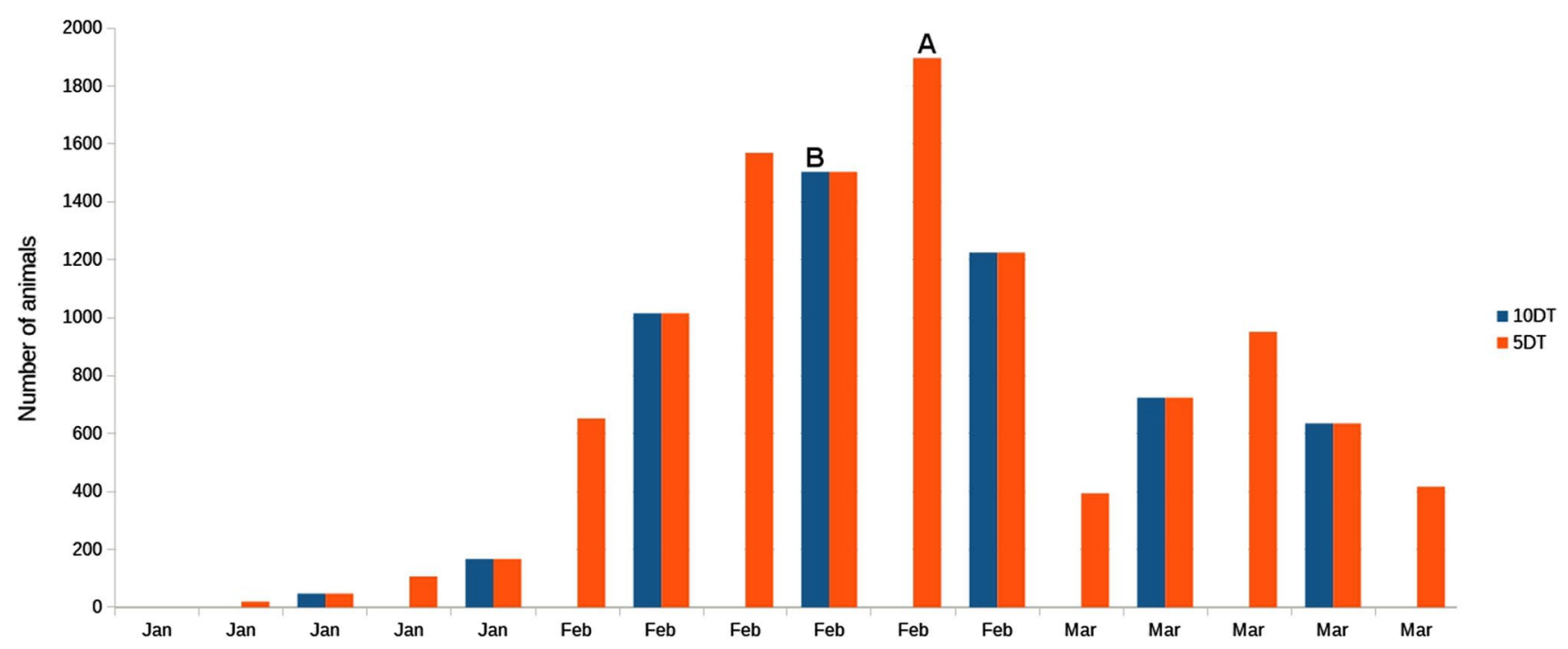

Fig. 4 The counts of Antarctic fur seals (only ASPA 151) with 5DT and 10DT methods between January and March in 2017. Letters A, B denote significantly $(P<0.0001)$ the different number of animals on peaks

Table 2 Total number of Antarctic fur seals including leucistic individuals on LR shore as assessed by 10DT $\left(\mathrm{N}_{10 \mathrm{DT}}\right)$ and RDM $\left(\mathrm{N}_{\mathrm{RDM}}\right)$ in seasons 2011-2018

\begin{tabular}{lccl}
\hline Season & Total $\mathrm{N}_{\text {10DT }}$ & $\begin{array}{l}\text { Leucistic indi- } \\
\text { viduals } \mathrm{N}_{\text {10DT }}\end{array}$ & $\begin{array}{l}\text { Leucistic } \\
\text { individuals } \\
\mathrm{N}_{\text {RDM }}\end{array}$ \\
\hline $2011 / 2012$ & 5682 & 1 & 2 \\
$2012 / 2013$ & 1266 & 0 & 2 \\
$2013 / 2014$ & 5618 & 0 & 0 \\
$2014 / 2015$ & 5089 & 0 & 1 \\
$2015 / 2016$ & 11,764 & 5 & 18 \\
$2016 / 2017$ & 6430 & 3 & 11 \\
$2017 / 2018$ & 8070 & 5 & 13 \\
Total & 43,919 & 14 & 47 \\
\hline
\end{tabular}

the on-shore occurrence of moulting males was relatively stable with the increase of abundance as the summer season progressed. Since leucistic individuals stayed on-shore for 1-2 days usually, it can be hypothesised that the observation of migrating Antarctic fur seals every 3 days does not involve the same individuals. With more frequent counts in the season 2017/2018, we were able to count more individuals in total, whilst daily inspections provided more records of leucistic individuals compared to earlier studies (e.g. Aquayo 1978; Cárdenas and Yáñez 1983; Sierakowski 1991; Romero and Tirira 2017).

From 1970 to 2006, the increase of annual peaks from 447 to 2920 individuals was observed at Cape Lions Rump (Angiel and Korczak-Abshire 2011), which appears to follow the general patterns of recovery after species extermination (e.g. Bengtson et al. 1990). Although the migrations of Antarctic predators and the selection of habitats are affected by the changes in the range and thickness of the sea ice cover (e.g. Costa and Crocker 1996), fluctuations in the Euphausiacea abundance (e.g. Salwicka and Rakusa-Suszczewski 2002; Forcada et al. 2005) or by the anthropogenic pollution and tourism (Bonner 1978; Salwicka and Stonehouse 2000; Engelhard et. al. 2001; Van Polanen et al. 2008), it seems that current abundance of this species on LR shore is equilibrated. Also, the changes in climate parameters, observed in the Antarctic region since 1950 (e.g. Ducklow et al. 2007; Znoj et al. 2017) and El Niño-Southern Oscillation (ENSO) may have caused the long-term fluctuations in the number of pinnipeds (Testa et al. 1991). According to Salwicka and Rakusa-Suszczewski (2002), in the years of a strong ENSO event, which causes low food availability (krill biomass) at South Georgia (Forcada et al. 2005), the nonbreeding Antarctic fur seal males are being out-competed by breeding females and they search for food in other areas. It is worth noting that in our study the highest peak of fur seal abundance (3487 individuals) on LR shore (27 February 2016) coincided with a strong ENSO event (NOAA 2019).

The increase in the number of moulting males as season progressed, observed in the present study, may be related to the termination of breeding season by Pygoscelis penguins (Trivelpiece et al. 2007; Sierakowski et al. 2017), which are feeding competitors for the fur seals. When the Pygoscelis penguins leave the LR, summer peaks of A. gazella abundance are mostly observed (from mid-February to midMarch). These seal individuals could origin from the local breeding populations from South Shetlands (Aquayo 1978; Acevedo et al. 2009). Also, since at the end of the fur seal breeding season the males migrate from South Georgia to 
the South Orkney Islands (Boyd et al. 1998) not to compete with nursing females, their migration further south (e.g. to Deception Island) with the stop on King George Island is highly probable.

Our results confirm the presence of leucistic Antarctic fur seals in the South Shetlands region including King George Island (Aquayo 1978; Cárdenas and Yáñez 1983; Sierakowski 1991), Robert Island (Romero and Tirira 2017) and nearby Livingston Island (Acevedo et al. 2009). However, the temporal patterns of land residency at LR were unknown. Our observations show that during the austral summer migration, the Antarctic fur seals stop in a given location for a short time and then leave. Since for most cases the duration of land stay of leucistic individuals did not exceed 1 day, we assume that the seals observed daily are different individuals. Also, the records of leucistic individuals over the period under investigation enabled us to find the tendency for the increase in the number of leucistic animals in the successive years although the total population remained unchanged. First incidence of a leucistic individual was noted in 1933 for the population of South Georgia (Bonner 1968) and leucistic animals are relatively prevalent there (Hofmeyr et al. 2005), which might be a result of a strong historical bottleneck (Hoffman et al. 2011, 2018). Leucistic animals were also observed in the South Shetlands, Bouvetøya and Marion Island (Hofmeyr et al. 2005; Wege et al. 2015), Îles Kerguelen, Macquarie Island, Îles Crozet and Heard Island (Hoffman et al. 2018). Analysis of the polymorphism in the melanocortin 1 receptor gene, responsible for cream-coloured phenotype in fur seals, indicates a global cline in the frequency of colour polymorphism and suggests a limited contribution of gene flow between South Georgia and other populations (Hoffman et al. 2018). However, Bonin et al. (2013) concluded that genetic differences (analyses of microsatellites and mitochondrial hypervariable region 1) between populations from South Georgia and the South Shetlands not necessarily preclude ongoing migration. Therefore, the question whether the tendency for increasing occurrence of leucistic fur seals on-shore LR may be explained by stronger migration patterns from South Georgia to the South Shetlands or by the increasing number of leucistic individuals in the global A. gazella population needs further studies.

Since leucistic individuals were usually not observed for more than 1-2 days, we speculate that their observations may be helpful in preliminary determination of daily rotations of population of Antarctic fur seals in a non-sedentary moulting season. Although the use of albinism as the natural marker for population rotation studies could be limited due to increased susceptibility to infections, reduced heat absorption ability, and other health problems affecting survival rate (see Hain and Leatherwood 1982), it seems that for shorttimed study leucism it is an effective indicator. However, for more accurate determination of population rotation, studies including implementation of satellite transmitting location tags are certainly needed.

Thanks to the 5DT, we managed to capture more precisely the peak of the Antarctic fur seals number. This shows that more frequent transects are feasible in regular monitoring of Antarctic fur seals and prevent underestimation of data recorded with the standard every 10 days method. Therefore, more efficient census may reflect the size of the migrant population with more accuracy.

Acknowledgements The authors wish to thank Piotr Angiel who collected the GIS data and developed the basis for the map presented in Fig. 2, Hanna Szulczewska and Joseph C. Abshire for English proofreading of this manuscript and all persons involved in Lions Rump CEMP site monitoring in 2011-2018. The data used in this paper were collected with the support of The Henryk Arctowski Polish Antarctic Station. The research was funded by the National Science Centre, 2017/01/X/NZ8/02078 MINIATURA Grant. The authors would like to express their sincere gratitude to dr Greg Hofmeyr, dr Andrew Lowther and dr Javier Negrete for theirs constructive comments which helped to improve the original version of the article.

\section{Compliance with ethical standards}

Conflict of interest The authors declare no conflict of interests.

Open Access This article is licensed under a Creative Commons Attribution 4.0 International License, which permits use, sharing, adaptation, distribution and reproduction in any medium or format, as long as you give appropriate credit to the original author(s) and the source, provide a link to the Creative Commons licence, and indicate if changes were made. The images or other third party material in this article are included in the article's Creative Commons licence, unless indicated otherwise in a credit line to the material. If material is not included in the article's Creative Commons licence and your intended use is not permitted by statutory regulation or exceeds the permitted use, you will need to obtain permission directly from the copyright holder. To view a copy of this licence, visit http://creativecommons.org/licenses/by/4.0/.

\section{References}

Acevedo J, Torres D, Aguayo-Lobo A (2009) Rare piebald and partially leucistic Antarctic fur seals, Arctocephalus gazella, at Cape Shirreff, Livingston Island, Antarctica. Polar Biol 32:41-45

Angiel PJ, Korczak-Abshire M (2011) Recent climate change effect on penguins and pinnipeds, King George Island, Antarctica. Can Antarct Res Network Newsl 30:10-15

Aquayo A (1978) The present status of the Antarctic fur seal Arctocephalus gazella, at South Shetland Islands. Polar Rec 19:167-176

Bengtson JL, Ferm LM, Härkönen TJ, Stewart BS (1990) Abundance of Antarctic fur seal in the South Shetland Islands, Antarctica, during the 1986/87 Austral Summer. In: Kerry K, Hempel G (eds) Antarctic ecosystems. Ecological change and conservation. Springer, Heidelberg, pp 265-270

Bonin CA, Goebel ME, Forcada J, Burton RS, Hoffman JI (2013) Unexpected genetic differentiation between recently recolonized populations of a long-lived and highly vagile marine mammal. Ecol Evol 3:3701-3712. https://doi.org/10.1002/ece3.732 
Bonner WN (1968) The fur seal of South Georgia. Brit Antarct Surv Sci Rep 56:1-81

Bonner WN (1978) Man's impact on seals. Mammal Rev 8:3-13

Boyd IL, McCafferty DJ, Reid K, Taylor R, Walker TR (1998) Dispersal of male and female Antarctic fur seals (Arctocephalus gazella). Can J Fish Aquat Sci 55:845-852

Cárdenas JC, Yáñez J (1983) Variaciones extremas de color del Lobo Fino Antártico, Arctocephalus gazella (Peters, 1875), en islas Shetland del Sur, Chile. (Pinnipedia: Otariidae). Serie Cient INACH 30:5-12

Costa DP, Crocker DE (1996) Marine mammals of the Southern Ocean. Antarct Res Ser 70:287-301

Ducklow HW, Baker K, Martinson DG, Quetin LB, Ross RM, Smith RC, Stammerjohn SE, Vernet M, Fraser W (2007) Marine pelagic ecosystems: the west Antarctic Peninsula. Philos T Roy Soc B 362:67-94

Engelhard G, Van den Hoff J, Broekman M, Baarspul ANJ, Field I, Burton HR, Reijnders PJH (2001) Mass of weaned elephant seal pups in areas of low and high human presence. Polar Biol 24:244-251

Forcada J, Trathan PN, Reid K, Murphy EJ (2005) The effects of global climate variability in pup production of Antarctic Fur Seals. Ecology 86:2408-2417

Gryz P, Gerlée A, Korczak-Abshire M (2018) New breeding site and records of king penguins (Aptenodytes patagonicus) on King George Island (South Shetlands, Western Antarctic). Polar Rec $54: 275-283$

Hain JH, Leatherwood S (1982) Two sightings of white pilot whales, Globicephala melaena, and summarized records of anomalously white cetaceans. J Mammal 63:338-343

Hinke JT, Barbosa A, Emmerson LM, Hart T, Juáres MA, Korczak-Abshire M, Milinevsky G, Santos M, Trathan PN, Watters GM, Southwell C (2018) Estimating nest-level phenology and reproductive success of colonial seabirds using time-lapse cameras. Methods Ecol Evol 9:1853-1863. https:// doi.org/10.1111/2041-210X.13015

Hoffman JI, Grant SM, Forcada J, Phillips CD (2011) Bayesian inference of a historical genetic bottleneck in a heavily exploited marine mammal. Mol Ecol 20:3989-4008

Hoffman JI, Bauer E, Paijmans AJ, Humble E, Beckmann LM, Kubetschek C, Christaller F, Kröcker N, Fuchs B, Moreras A, Shihlomule YD, Bester MN, Cleary AC, De Bruyn PJN, Forcada J, Goebel ME, Goldsworthy SD, Guinet C, Hoelzel AR, Lydersen C, Kovacs KM, Lowther A (2018) A global cline in a colour polymorphism suggests a limited contribution of gene flow towards the recovery of a heavily exploited marine mammal. R Soc Open Sci 5:1-9. https://doi.org/10.1098/rsos.181227

Hofmeyr GJG, Bester MN, Kirkman SP (2005) Leucistic Antarctic fur seals at Bouvetøya. Polar Biol 29:77-79

Hofmeyr GJG (2016) Arctocephalus gazella, Antarctic Fur Seal. In: The IUCN Red List of Threatened Species 2016: e.T2058A66993062. https://www.iucnredlist.org/speci es/2058/66993062. Accessed 10 Dec 2014

Jabłoński B, Krzemiński W, Zdzitowiecki K (1987) Distribution and Number of Fur Seals, Arctocephalus gazella (Peters 1875 of King George Island (South Shetlands). Acta Zool Cracov 30:119-136

Korczak-Abshire M, Węgrzyn PJ, Angiel PJ, Lisowska M (2013) Pygoscelid penguins breeding distribution and population trends at Lions Rump rookery, King George Island. Pol Polar Res 34:8799. https://doi.org/10.2478/popore
Korczak-Abshire M, Zmarz A, Rodzewicz M, Kycko M, Karsznia I, Chwedorzewska KJ (2019) Study of fauna population changes on Penguin Island and Turret Point Oasis (King George Island, Antarctica) using Unmanned Aerial Vehicle. Polar Biol 42:217-224. https://doi.org/10.1007/s00300-018-2379-1

NOAA (2019) Oceanic Niño Index, website address: https://www. climate.gov/news-features/understanding-climate/climate-varia bility-oceanic-ni\%C3\%B1o-index. Accessed 18 Sept 2019

Reid K, Davis D, Staniland IJ (2006) Spatial and temporal variability in the fish diet of antarctic fur seal (Arctocephalus gazella) in the Atlantic sector of the Southern Ocean. Can J Zool 84:1025-1037. https://doi.org/10.1139/Z06-071

Romero V, Tirira DG (2017) Leucistic Antarctic fur seal (Arctocephalus gazella) at Robert Island, South Shetland Islands, Antarctica, with a note on colour morph nomenclature. Polar Biol 40:18931897. https://doi.org/10.1007/s00300-016-2069-9

Salwicka K, Rakusa-Suszczewski S (2002) Long-term monitoring of Antarctic Pinnipeds in Admiralty Bay (South Shetlands, Antarctica). Acta Theriol 47:443-457

Salwicka K, Stonehouse B (2000) Visual monitoring of heartbeat and respiration in Antarctic seals. Pol Polar Res 21:189-197

Sierakowski K (1991) Birds and mammals in the region of SSSI No 8 in the season 1988/89 (South Shetlands, King George Island, Admiralty Bay. Pol Polar Res 12:25-54

Sierakowski K, Korczak-Abshire M, Jadwiszczak P (2017) Changes in bird communities of Admiralty Bay, King George Island (West Antarctica): insights from monitoring data (1977-1996). Pol Polar Res 38:231-262

Testa JW, Rounsevell D, Laws RM, Oehlert G, Ainley DG, Bengtson JL, Siniff DB (1991) Temporal variability in Antarctic marine ecosystems: periodic fluctuation in the phocid seals. Can J Fish Aquat Sci 48:631-639

Trivelpiece WZ, Buckelew S, Reiss C, Trivelpiece SG (2007) The winter distribution of chinstrap penguins from two breeding sites in the South Shetland Islands of Antarctica. Polar Biol 30:1231-1237

Udevitz MS, Jay CV, Cody MB (2005) Observer variability in pinniped of walruses at haul-out sites counts: ground-based enumeration. Mar Mammal Sci 21:108-120

Van Polanen PT, Giese M, Hindell M (2008) A preliminary investigation of the effect of repeated pedestrian approaches to Weddell seals (Leptonychotes weddellii). Appl Anim Behav Sci 112:205-211

Weddell J (1825) A voyage towards the South Pole, performed in the years 1822-1824. A\&R Spottiswoode, London

Wege M, Postma M, Tosh CA, De Bruyn PJN, Bester MN (2015) First confirmed record of a leucistic Antarctic fur seal pup born outside the Scotia Arc Islands. Polar Biol 38:569-571

Znoj A, Chwedorzewska KJ, Androsiuk P, Cuba-Diaz M, Giełwanowska I, Koc J, Korczak-Abshire M, Grzesiak J, Zmarz A (2017) Rapid environmental changes in the Western Antarctic Peninsula region due to climate change and human activity. Appl Ecol Environ Res 15:525-539. https://doi.org/10.15666/ aeer/1504_525539

Publisher's Note Springer Nature remains neutral with regard to jurisdictional claims in published maps and institutional affiliations. 